\title{
Effect of various nanoadditives on the performance and emission characteristics of a diesel engine fuelled with jojoba biodiesel - diesel blends: A review
}

\author{
Swati Agarwal* \& Suphiya Khan \\ Department of Bioscience and Biotechnology, Banasthali University, Rajasthan 304 022, India
}

\section{Article history}

Received: 25 July 2019

Accepted: 17 August 2019

Published: 03 October 2019

\section{Publisher}

Horizon e-Publishing Group

*Correspondence
Swati Agarwal
$\square$ swatiagarwal1406@gmail.com

\begin{abstract}
The review reports the results of various researches work on the engine performance and emission characteristics of diesel engine using different nanoadditives in jojoba biodiesel - diesel blends. Blending of diesel with biodiesel in a diesel engine has gained importance, due to its economical and environmental benefits. Jojoba biodiesel gained an importance as an alternative fuel over conventional diesel fuel even with their unfavorable effects of power reduction. The wide spread usage of nanoadditives to improve the combustion quality may be a good solution of this problem. Blending of nanoparticles as an additives in biodiesel - diesel blends improves the thermophysical properties, such as thermal conductivity, mass diffusivity and high surface area-tovolume ratio. Based on the results available in the literature, it has been found that nanoadditives with jojoba biodiesel - diesel blends improve the performance of diesel engine and reduced the emission of toxic gases depending upon the dosage of the nanoadditives.
\end{abstract}

Keywords: Nanoadditives; Jojoba biodiesel; Thermophysical; Combustion quality

Citation: Agarwal S, Khan S. Effect of various nanoadditives on the performance and emission characteristics of a diesel engine fuelled with jojoba biodiesel - diesel blends: A review. Plant Science Today 2019;6(4):485-490. https://doi.org/10.14719/pst.2019.6.4.601

Copyright: (C) Agarwal \& Khan (2019). This is an open-access article distributed under the terms of the Creative Commons Attribution License, which permits unrestricted use, distribution, and reproduction in any medium, provided the original author and source are credited (https://creativecommons.org/licenses/by/4.0/).

Indexing: Plant Science Today is covered by Scopus, Web of Science, BIOSIS Previews, ESCI, CAS, AGRIS, CABI, Google Scholar, etc. Full list at http://www.plantsciencetoday.online

\section{Introduction}

Nowadays, concerns have been raised about the limited resources of fuel oil and the environmental issues which directly linked to the combustion of these fuels (1). The above-mentioned issues motivated the researchers to find out some new alternative and renewable sources of energy, which are more environmental friendly. Diesel engine plays an important role in industrial sectors due to their easy, high reliability, durability and good exhaust emission behavior. Diesel engines can use variety of fuels such as diesels, fuel oil, biodiesel, etc (2).

Biodiesel is considered as a renewable, clean burning diesel and a better replacement of available conventional petroleum based fuels. The edible (sunflower, soybean, rapeseed etc.) and nonedible vegetable oils (palm, jatropha, jojoba etc.) 
were served as potential feedstock to produce biodiesel (3). Non-edible oils as feedstock for biodiesel preparation gained much more attention due to their lower demand in comparison with food crops (4). Jojoba, Simmondsia chinensis (Link) Schneider, belongs to family Simmondsiaceae, is a known non edible oilseed crop. Jojoba is a native shrub of Northern Mexico, USA and Baja California (5). Raw oils can be converted into their methyl esters (biodiesel) using different methods, out of them transesterification method is commonly used because it is simple, cost effective and produce good quality biodiesel (6).

Biodiesel can be directly used in diesel engines but it's better to improve its quality by some modification. The fuel modification can be achieved by several methods such as blending of solvents, market diesel, raw plant oil, nanoparticles etc. (7). These modifications can help the researchers to achieve the specific fuel properties and to improve the engine performance. With the help of nanotechnology nano-scale energetic materials are produced which are much more advantageous as are nano-sized materials (8). Most of the researchers conducted their experiments with metal nanoadditives (9), metal oxide nanoadditives (10), magnetic nano fluid additives (11)and water diesel nanoparticle, emulsion (12), water diesel carbon nano tube emulsion (13), and nano organic additives (14) to the diesel fuel. There are only a group of researchers were found in previous literature who worked on jojoba biodiesel - diesel blends with nanoparticle addition (15-20).

In 2014, Attia and his coworkers carried out an experiment to study the effect of $\mathrm{Al}_{2} \mathrm{O}_{3}$ nanoparticles as nanoadditives in jojoba biodiesel - diesel blends on single cylinder diesel engine and they found a slight improvement in engine performance and lower $\mathrm{CO}$ and $\mathrm{HC}$ emission in comparison to blend without $\mathrm{Al}_{2} \mathrm{O}_{3}$ nanoadditive (15). Later the same group of researchers continues their work by using different nanoadditives $\left(\mathrm{Al}_{2} \mathrm{O}_{3}\right.$, MWCNTs) with jojoba biodiesel - diesel blends (16-19). However, in 2018 they again conducted their experiment using different nanoadditive made of titanium oxide $\left(\mathrm{TiO}_{2}\right)$ mixed with jojoba biodiesel - diesel - n-hexane blend (J30D5H) and study their effect on diesel engine performance and exhaust gas emission (20).

\section{Effects of various jojoba biodiesel blend + nanoadditives on engine performance}

\section{Brake thermal efficiency}

Brake thermal efficiency is defined as the relationship between engines generated break power and transferred energy to engine. The performance of engine using fuel blends can be estimated by brake thermal efficiency. Nanoparticles addition to fuel blends improve the combustion efficiency by improving the heat mass transport properties (21).

There are investigations on the variation in brake thermal efficiency using jojoba biodiesel blends with $\mathrm{Al}_{2} \mathrm{O}_{3}$ NPs at dosage levels of 10 and $50 \mathrm{mg}$ and diesel (15). The value of brake thermal efficiency is increased in comparison with pure diesel. This may be due to the effect of nanoparticle on biodiesel blend, which improve its surface-area-to-volume ratio leads to react more amount of fuel with air.

Another study reported the blending of nhexane with jojoba biodiesel blends with $\mathrm{TiO}_{2}$ nanoadditives improved the spray characteristics by decreasing the viscosity of the blended fuels. Low viscosity helps in increasing the fuel combustion and thus the brake thermal efficiency gets increased. The addition of $\mathrm{TiO}_{2}$ nanoparticles increased the brake thermal efficiency by $15 \%$ and boosts the performance of engine consequently (20).

\section{Brake specific fuel consumption}

Brake specific fuel consumption is defined as the ratio of the fuel used by engine to the power generated by engine with respect to the time (22). Engine load is an important parameter because as we increase the load of the engine, the value of brake specific fuel consumption gets reduced (23). Other than engine load some more parameters (calorific value, density, volumetric fuel injection and viscosity) also affects the value of brake specific fuel consumption (24).

Attia and his co-workers investigated the effect of $\mathrm{Al}_{2} \mathrm{O}_{3}$ NPs on jojoba biodiesel-diesel blends. The result showed that there was a considerable change in fuel properties. The authors reported that the fuel sample JB20DA produced the maximum amount of BSFC ( 760 g/ $\mathrm{kW}-\mathrm{h})$ at $50 \mathrm{mg} \mathrm{Al}_{2} \mathrm{O}_{3}$ additive concentration in comparison to the other blends (15).

One of the recent studies conducted in 2018 , showed the reduction in brake specific fuel consumption about $12 \%$ with the addition of $\mathrm{Al}_{2} \mathrm{O}_{3}$ nanoparticles (19). The minimum brake specific fuel consumption is achieved, which was slightly lower than diesel fuel at the dose levels of $30-40 \mathrm{mg} / \mathrm{l}$. Further addition of $\mathrm{Al}_{2} \mathrm{O}_{3}$ nanoparticles beyond these levels; increase the brake specific fuel consumption value. Another study conducted by same group of researchers found the same results with $\mathrm{TiO}_{2} \mathrm{NPs}$ (19).

\section{Effects of various jojoba biodiesel blend + nanoadditives on engine combustion characteristics}

\section{Ignition delay}

The ignition delay period in the diesel engine has a significant influence on engine design and performance. The ignition delay can be divided into two parts, physical delay and chemical 
delay. It depends mainly on fuel properties and engine operating conditions in conjunction with fuel injection system features. The addition of nanoadditives leads to a decrease the ignition delay (25). The reason is attributed to the higher surface area to volume ratio and higher thermal conductivity of nanoadditives which enhance the evaporation rate resulting in a reduction in physical delay (26).

In an experimental study conducted by El-Seesy et al. with multi well carbon nanotubes (MWCNTs) mixed in a jojoba biodiesel-diesel blend in order to investigate the combustion characteristics of diesel engine, revealed that the effect of MWCNTs shortens the ignition delay as a result in higher gross heat release rate and advancement of the peak gross heat release rate (18). It finally resulted in better atomization of fuel and proper air fuel mixing.

El-Seesy et al. again conducted an experiment on alumina nanoparticles with diesel jojoba biodiesel fuel in a diesel engine revealed decrease ignition delay. The ignition delay for JB20D mixture fuel is slightly higher by about $0.5 \mathrm{CA}$ as compared to diesel fuel. This is attributed to the higher viscosity and molecular weight of JB20D, which lead to an increase of fuel droplet size and vaporization time (19). The reason is attributed to the higher surface area to volume ratio and higher thermal conductivity of the $\mathrm{Al}_{2} \mathrm{O}_{3}$ nanoparticles which enhanced the evaporation rate, resulting in a reduction in physical delay. These results were confirmed with others cited in the literature (21).

\section{Cylinder Pressure}

The cylinder gas pressure of diesel, diesel biodiesel fuel and nanoparticle blended diesel biodiesel fuel have shown near similar trends of variation with crank angle. The change of cylinder pressure as a function of the crank angle during the end of the compression stroke and throughout the initial part of the expansion stroke was recorded for the test fuels. With the advancement in fuel injection timing, along with high injection pressure of biodiesel fuels, the combustion process starts earlier which provides shorter ignition delay might be the possible reason for high cylinder pressure (27).

The addition of MWCNTs to JB20D mixture led to accelerating combustion process. The MWCNTs has a higher thermal conductivity which is about 2000 times greater than that of JB20D blends. Therefore, the evaporation rate of fuel droplet is increased, which resulted in a shortened ignition delay. Another factor is the higher surface area to volume ratio of Multiwalled carbon nanotubes, which enhanced the heat transfer between the particles and the fuel droplets resulted in increased peak pressures (18). Few other studies also obtained similar results when using MWCNTs additives to dieselbiodiesel blended fuel (28-30).

\section{Effects of various jojoba biodiesel blend + nanoadditives on engine emission performance}

Basically engine emissions are divided into two different categories, the first one is produced due to the results of high temperature of combustion chamber like NOx and second one is produced resulting from incomplete combustion of fuel and lower combustion temperature like $\mathrm{HC}$ and $\mathrm{CO}_{2}$ (29). $\mathrm{CO}$ is produced as a result of incomplete combustion or low combustion time in the engine or lower temperature of the combustion chamber (31). On the other hand, incomplete combustion of diesel or fuel would lead to the production of the HC. Soot is produced by incomplete combustion of the hydrocarbon fuel and is observed in the dark exhaust effluents. In comparison with petrol based engines, diesel engine emits very low concentration of hydrocarbons (HC), Nitrogen oxides (NOx) and carbon oxides (CO, Cox). But with the help of fuel modifications (nanoadditives) these emissions will further be decreased. In the following section, we summaries the effect of different nanoadditives with different jojoba biodiesel blends on the engine emission performance.

\section{Carbon monoxide emission}

Many authors concluded that as they increase the proportion of jojoba biodiesel and nanoadditives in blends, the carbon monoxide emission gets decreased (Table 1). Addition of nanoadditives to blends increase the amount of oxygen will result in comprehensive fuel combustion (32).

The aluminium oxide $\left(\mathrm{Al}_{2} \mathrm{O}_{3}\right)$ nanoparticles were added to jojoba biodiesel blends in fractions of 10 and $50 \mathrm{mg}$, the result suggested that there were considerable reduction in $\mathrm{CO}$ emission $(16,19)$. Lower CO emission probably due to the increase in surface-to-volume ratio, leads to the great mixing of air to fuel resulting in higher catalytic activity (33). It was found that the $\mathrm{CO}$ emissions were lower in compare to either diesel fuel or JB20D fuel blend, irrespective of the nanoadditive concentration. The maximum reduction in $\mathrm{CO}$ emissions was found at the dose of $20-30 \mathrm{mg} / \mathrm{l}$. These results were supported by the previous findings (34-36).

The multi well carbon nanotubes (MWCNTs) as additive were also used by the same group of researchers (16-18). They found the reduced emission of $\mathrm{CO}$ at $20-40 \mathrm{mg}$ MWCNTs. One of the other studies showed the effect of titanium oxide $\left(\mathrm{TiO}_{2}\right)$ nanoparticle with jojoba biodiesel + n-hexane + diesel blends (J30D5H). They concluded that at the 
Table 1. Comparison of emission parameters with various jojoba biodiesel blends and nanoadditives

\begin{tabular}{|c|c|c|c|c|c|c|}
\hline \multirow{2}{*}{ Engine Specification } & \multirow{2}{*}{ Biodiesel blends } & \multirow{2}{*}{ NPs Type and Dosage } & \multicolumn{3}{|c|}{ Lowest Emission } & \multirow[t]{2}{*}{ Reference } \\
\hline & & & $\mathrm{CO}$ & NOx & HC & \\
\hline $\begin{array}{l}\text { Single cylinder, direct } \\
\text { injection diesel engine }\end{array}$ & $\begin{array}{l}\text { Jojoba biodiesel + } \\
\text { diesel blend JB20D }\end{array}$ & $\begin{array}{l}\mathrm{Al}_{2} \mathrm{O}_{3} \mathrm{Nps} \\
10-50 \mathrm{mg}\end{array}$ & $20-30 \mathrm{mg}$ & $20-30 \mathrm{mg}$ & $20-30 \mathrm{mg}$ & (19) \\
\hline $\begin{array}{l}\text { Single cylinder, direct } \\
\text { injection diesel engine }\end{array}$ & $\begin{array}{l}\text { Jojoba biodiesel + } \mathrm{n} \\
\text { hexane + diesel } \\
\text { blend J30D5H }\end{array}$ & $\begin{array}{l}\mathrm{TiO}_{2} \mathrm{NPs}, \\
25 \mathrm{mg} \text { and } 50 \mathrm{mg}\end{array}$ & $50 \mathrm{mg}$ & $0 \mathrm{mg}$ & $25 \mathrm{mg}, 50 \mathrm{mg}$ & (20) \\
\hline $\begin{array}{l}\text { Single cylinder, direct } \\
\text { injection diesel engine }\end{array}$ & $\begin{array}{l}\text { Jojoba biodiesel + } \\
\text { diesel blend JB20D }\end{array}$ & $\begin{array}{l}\text { Carbon nanotubes } \\
10-50 \mathrm{mg}\end{array}$ & $20-40 \mathrm{mg}$ & $20 \mathrm{mg}$ & $20-40 \mathrm{mg}$ & $(16-18)$ \\
\hline $\begin{array}{l}\text { Single cylinder, direct } \\
\text { injection diesel engine }\end{array}$ & $\begin{array}{l}\text { Jojoba biodiesel + } \\
\text { diesel blend JB20D }\end{array}$ & $\begin{array}{l}\mathrm{Al}_{2} \mathrm{O}_{3} \mathrm{Nps} \\
10-50 \mathrm{mg}\end{array}$ & $30 \mathrm{mg}$ & $20 \mathrm{mg}$ & $30 \mathrm{mg}$ & (15) \\
\hline
\end{tabular}

concentration of $50 \mathrm{mg}\left(\mathrm{TiO}_{2}\right)$ to jojoba biodiesel blend reduced CO emission by $20 \%$ (18).

\section{Nitrogen oxide emissions}

Nitrogen oxides (NOx) in the exhaust emission consist of nitric oxide (NO) and nitrogen dioxide $\left(\mathrm{NO}_{2}\right)$ (37). Many researchers blended different additives (metal-based, oxygenated, cetane improver etc) with biodiesel to decrease the emission of NOx (38). But the investigations revealed that the emission of NOx gets increased with the increase in concentration of blended nanoparticles (29) The increase in NOx emission may be due to the increase in cylinder temperature and thus the existence of a greater chance for thermal NOx formation (39).

An earlier study used $\mathrm{Al}_{2} \mathrm{O}_{3} \mathrm{NPs}$ in jojoba biodiesel blends to improve the engine emission performance and they found the $20 \mathrm{mg}$ concentration of $\mathrm{Al}_{2} \mathrm{O}_{3}$ NPs reduced the NOx emission (15). Same results were obtained by using Multi walled carbon nanotubes (MWCNT) $20 \mathrm{mg}(16,17)$ with jojoba biodiesel blends. The above studies showed the reduction of NOx emission at $20 \mathrm{mg}$ among different concentration of NPs, but showed higher emission in comparison with jojoba biodiesel diesel blend without NPs. In contrast, lower emission of NOx with NPs was observed in comparison to that of without NPs addition (18).

\section{Unburned hydrocarbons (UHC) emissions}

Incomplete combustion of diesel or fuel leads to the emission of unburned hydrocarbons (UHC). The incomplete combustion due to incomplete/ distorted flame propagation, because of either too rich or too lean mixture, low charge temperature and less injection pressure inside the cylinder are found to be liable for higher level of hydrocarbon emissions (40). Experimental studies on nanoparticle added diesel, biodiesel fuels in a CI engine showed that nanoparticle inclusion with fuel acts as oxidizing catalyst accelerates the flame propagation inside the cylinder, which lowers the carbon activation temperature and promotes more complete combustion. All these factors mainly inhibit the hydrocarbon emissions from nanoparticle mixed diesel, biodiesel fuel blends (41).
The MWCNTs additives had a remarkably positive effect on UHC emissions (18). Using JB20D led to a considerable increase in UHC emissions compared to pure diesel fuel. The reason for this influence may be due to the prolonged delay period and higher values of viscosity of JB20D that disturb the fuel atomization and vaporization and thus, a longer time was required to attain complete combustion. Another reason may be due to the incorrect combustion of layers approaching the cylinder wall. These layers would carry a great fraction of hydrocarbons which escape from the denser and longer penetrated fuel spray in case of JB20D, and hence more UHC was emitted in the exhaust gases. Similar trends of results were also quoted by various researchers when experimenting with different blends of nanoparticle diesel, biodiesel fuels in a CI engine $(35,42)$.

\section{Conclusion}

Based on the above review, it is understood that nanoadditives plays an important role in improving the fuel combustion, enhancing the engine and reduced the exhaust emissions. These engine properties depends upon the type of base fuel used, nanoadditive concentration, blending technique and the operation condition of the diesel engine. Nanoadditives like $\mathrm{Al}_{2} \mathrm{O}_{3}$, MWCNTs and $\mathrm{TiO}_{2}$ shows good results as additives with jojoba biodiesel - diesel blends in all aspects. Therefore, blending the optimal range of nanoadditive is the key to get enhanced performance and reduced emission in a diesel engine.

\section{Competing interest}

The authors declare that they have no competing interests.

\section{Acknowledgement}

Author would like to thank the computational facility provided by Reena Mishra, Department of Bioscience and Biotechnology, Banasthali Vidyapith. 


\section{Author's contribution}

SA design and writes the manuscript. SK coordinates and corrects the manuscript. Both the authors read and approved the final manuscript.

\section{References}

1. Dincer I. Renewable energy and sustainable development: a crucial review. Renew Sust Energ Rev. 2000:14(2):157-175. https://doi.org/10.1016/S1364$\underline{0321(99) 00011-8}$

2. Agarwal AK. Biofuels (alcohols and biodiesel) applications as fuels for internal combustion engines. Prog Energ Combust. 2007;33(3):233-71. https://doi.org/10.1016/j.pecs.2006.08.003

3. Ramkumar S, Kirubakaran V. Biodiesel from vegetable oil as alternate fuel for CI engine and feasibility study of thermal cracking: a critical review. Energ Convers Manage. https://doi.org/10.1016/i.enconman.2016.03.071

4. Mata TM, Martins AA, Caetano NS. Microalgae for biodiesel production and other applications: a review. Renew Sust Energ Rev. 2010;14(1):217-32. https://doi.org/ 10.1016/j.rser.2009.07.020

5. Knoepfler NB, Vix HL. Vegetable Oils, Review of Chemistry and Research Potential of Simmondsia chinensis (Jojoba) Oil. J Agric Food Chem. 1958;6(2):11821. https://doi.org/10.1021/jf60084a005

6. Karmakar A, Karmakar S, Mukherjee S. Properties of various plants and animals feedstocks for biodiesel production. Bioresour Technol. 2010;101(19):7201-10. https://doi.org/10.1016/j.biortech.2010.04.079

7. Atabani AE, Silitonga AS, Ong HC, Mahlia TM, Masjuki $\mathrm{HH}$, Badruddin IA, Fayaz H. Non-edible vegetable oils: a critical evaluation of oil extraction, fatty acid compositions, biodiesel production, characteristics, engine performance and emissions production. Renew Sust Energ Rev. 2013;1(18):211-45. https://doi.org/10.1016/j.rser.2012.10.013

8. Robichaud CO, Uyar AE, Darby MR, Zucker LG, Wiesner MR. Estimates of upper bounds and trends in nano-TiO2 production as a basis for exposure assessment. Environ Sci Technol. 2009;43(12):4227-33. https://doi.org/10.1021/ es8032549

9. Mehta RN, Chakraborty M, Parikh PA. Nanofuels: Combustion, engine performance and emissions. Fuel. 2014;15(120):91-97. https://doi.org/10.1016/j.fuel.2013.12.008

10. Lenin MA, Swaminathan MR, Kumaresan G. Performance and emission characteristics of a DI diesel engine with a nanofuel additive. Fuel. 2013;1(109):362-5. https://doi.org/10.1016/j.fuel.2013.03.042

11. Sabet Sarvestany N, Farzad A, Ebrahimnia-Bajestan E, Mir M. Effects of magnetic nanofluid fuel combustion on the performance and emission characteristics. J Disper Sci Technol. 2014;35(12):1745-50. https://doi.org/10.1080/01932691.2013.874296

12. Kao MJ, Ting CC, Lin BF, Tsung TT. Aqueous aluminum nanofluid combustion in diesel fuel. J Test Eval. 2007;36(2):186-90. https://doi.org/10.1520/JTE100579

13. Basha JS, Anand RB. An experimental investigation in a diesel engine using carbon nanotubes blended waterdiesel emulsion fuel. Proceedings of the Institution of Mechanical Engineers, Part A: J Power Energ.
2011;225(3):279-88. https://doi.org/10.1177/2041296710394247

14. Yang WM, An H, Chou SK, Vedharaji S, Vallinagam R, Balaji M, Mohammad FE, Chua KJ. Emulsion fuel with novel nano-organic additives for diesel engine application. Fuel. 2013;104:726-31. https://doi.org/10.1016/j.fuel.2012.04.051

15. Attia AM, El-Seesy AI, El-Batsh HM, Shehata MS. Effects of alumina nanoparticles additives into jojoba methyl ester-diesel mixture on diesel engine performance. In ASME 2014 Int Mech Eng Congress Expo 2014 Nov 14 (pp. V06BT07A019-V06BT07A019). American Society of Mechanical Engineers. http://doi.org/10.1115/JMECE2014$\underline{39988}$

16. EL-Seesy AI, Abdel-Rahman AK, Bady M, Ookawara S. The influence of multi-walled carbon nanotubes additives into non-edible biodiesel-diesel fuel blend on diesel engine performance and emissions. Energy Procedia. 2016;100:166-72 https://doi.org/10.1016/j.egypro.2016.10.160

17. EL-Seesy AI, Abdel-Rahman AK, Hassan H, Ookawara S, Hawi M. Investigation of the performance of a diesel engine fueled by biodiesel-diesel fuel mixture with addition of nanoparticles. InASME 2017 Power Conference Joint With ICOPE-17 collocated with the ASME 2017 11th International Conference on Energy Sustainability, the ASME 2017 15th International Conference on Fuel Cell Science, Engineering and Technology, and the ASME 2017 Nuclear Forum 2017a Jun 26 (pp. V001T04A005-V001T04A005). American Society of Mechanical Engineers. http://doi.org/10.1115/POWER-ICOPE2017-3055

18. El-Seesy AI, Abdel-Rahman AK, Bady M, Ookawara SJ. Performance, combustion and emission characteristics of a diesel engine fueled by biodiesel-diesel mixtures with multi-walled carbon nanotubes additives. Energy Convers Manage. 2017b;135:373-93. https://doi.org/10.1016/j.enconman.2016.12.090

19. El-Seesy AI, Attia AM, El-Batsh HM. The effect of Aluminum oxide nanoparticles addition with Jojoba methyl ester-diesel fuel blend on a diesel engine performance, combustion and emission characteristics. Fuel. 2018a;224:147-66. https://doi.org/10.1016/j.fuel.2018.03.076

20. El-Seesy AI, Hassan H, Dawood A, Attia AM, Kosaka H, Ookawara S. Investigation of the Impact of Adding Titanium Dioxide to Jojoba Biodiesel-Diesel-N-Hexane Mixture on the Performance and Emission Characteristics of a Diesel Engine. InASME 2018b Internal Combustion Engine Division Fall Technical Conference 2018 Nov 4 (pp. V001T02A006-V001T02A006). American Society of Mechanical Engineers. 10.1115/ICEF2018-9647

21. Venu H, Madhavan V. Effect of Al2O3 nanoparticles in biodiesel-diesel-ethanol blends at various injection strategies: Performance, combustion and emission characteristics. Fuel. 2016 Dec 15;186:176-89. https://doi.org/10.1016/j.fuel.2016.08.046

22. Ghobadian B, Rahimi H, Nikbakht AM, Najafi G, Yusaf TF. Diesel engine performance and exhaust emission analysis using waste cooking biodiesel fuel with an artificial neural network. Renewable Energy. 2009 Apr 1;34(4):976-82. https://doi.org/10.1016/j.renene.2008.08.008

23. Chauhan BS, Kumar N, Cho HM. A study on the performance and emission of a diesel engine fueled with Jatropha biodiesel oil and its blends. Energy. 2012 Jan 1;37(1):616-22. https://doi.org/10.1016/j.energy.2011.10.043 
24. Agarwal D, Agarwal AK. Performance and emissions characteristics of Jatropha oil (preheated and blends) in a direct injection compression ignition engine. Applied Thermal Engineering. 2007 Sep 1;27(13):2314-23. https:// doi.org/10.1016/j.applthermaleng.2007.01.009

25. Karthikeyan S, Prathima A. Emission analysis of the effect of doped nano-additives on biofuel in a diesel engine. Energy Sources, Part A: Recovery, Utilization, and Environmental Effects. 2016 Dec 16;38(24):3702-08. https://doi.org/10.1080/15567036.2016.1166164

26. Gan Y, Qiao L. Combustion characteristics of fuel droplets with addition of nano and micron-sized aluminum particles. Combustion and Flame. 2011 Feb 1;158(2):354-68. https://doi.org/10.1016/j.combustflame.2010.09.005

27. Ranaware AA, Satpute ST. Correlation between effects of cerium oxide nanoparticles and ferrofluid on the performance and emission characteristics of a CI engine. JMCE. 2013;1:55-59.

28. Ghafoori M, Ghobadian B, Najafi G, Layeghi M, Rashidi A, Mamat R. Effect of nano-particles on the performance and emission of a diesel engine using biodiesel-diesel blend. IJAME. 2015;12:3097-3108. http://dx.doi.org/10.15282/ijame.12.2015.23.0258

29. Mirzajanzadeh M, Tabatabaei M, Ardjmand M, Rashidi A, Ghobadian B, Barkhi M, Pazouki M. A novel soluble nano-catalysts in diesel-biodiesel fuel blends to improve diesel engines performance and reduce exhaust emissions. $\quad$ Fuel. 2015;139:374-82. https://doi.org/10.1016/j.fuel.2014.09.008

30. Banapurmath NR, Sankaran R, Tumbal AV, Hunashyal $\mathrm{AM}$, Ayachit NH. Experimental investigation on direct injection diesel engine fuelled with graphene, silver and multiwalled carbon nanotubes-biodiesel blended fuels. IJAET. 2014;3(4):129-38. http://doi.org/10.1824/ijaet.59113

31. Agarwal AK, Srivastava DK, Dhar A, Maurya RK, Shukla PC, Singh AP. Effect of fuel injection timing and pressure on combustion, emissions and performance characteristics of a single cylinder diesel engine. Fuel. 2013;111:374-83.

https://doi.org/10.1016/j.fuel.2013.03.016

32. Tomar M, Kumar N. Influence of nanoadditives on the performance and emission characteristics of a CI engine fuelled with diesel, biodiesel, and blends-a review. Energ Source Part A. 2019;1-8. https://doi.org/10.1080/15567036.2019.1623347

33. Khond VW, Kriplani VM. Effect of nanofluid additives on performances and emissions of emulsified diesel and biodiesel fueled stationary CI engine: A comprehensive review. Renew Sust Energ Rev. 2016;59:1338-48. https://doi.org/10.1016/j.rser.2016.01.051

34. Ganesh D, Gowrishankar G. Effect of nano-fuel additive on emission reduction in a biodiesel fuelled CI engine. In2011 International conference on electrical and control engineering 2011 Sep 16 (pp. 3453-3459). IEEE. 10.1109/ICECENG.2011.6058240

35. Selvan VA, Anand RB, Udayakumar M. Effects of cerium oxide nanoparticle addition in diesel and dieselbiodiesel-ethanol blends on the performance and emission characteristics of a CI engine. J Eng Appl Sci. 2009;4(7):1819-6608.

36. Basha JS, Anand RB. Effects of alumina nanoparticles blended jatropha biodiesel fuel on working characteristics of a diesel. Int J Ind Eng Technol. 2010;2:53-62.

37. Mok YS, Huh YJ. Simultaneous removal of nitrogen oxides and particulate matters from diesel engine exhaust using dielectric barrier discharge and catalysis hybrid system. Plasma Chemistry and Plasma Processing. https://doi.org/10.1007/s11090-005-6817-9

38. Shaafi T, Sairam K, Gopinath A, Kumaresan G, Velraj R. Effect of dispersion of various nanoadditives on the performance and emission characteristics of a CI engine fuelled with diesel, biodiesel and blends-a review. Renew Sust Energ Rev. 2015;49:563-73. https://doi.org/10.1016/j.rser.2015.04.086

39. Ban-Weiss GA, Chen JY, Buchholz BA, Dibble RW. A numerical investigation into the anomalous slight NOx increase when burning biodiesel; a new (old) theory. Fuel Process Technol. 2007;88(7):659-67. https://doi.org/10.1016/j.fuproc.2007.01.007

40. Arcoumanis C, Bae C, Crookes R, Kinoshita E. The potential of di-methyl ether (DME) as an alternative fuel for compression-ignition engines: A review. Fuel. 2008;87(7):1014-30. https://doi.org/10.1016/j.fuel.2007.06.007

41. Kannan GR, Karvembu R, Anand R. Effect of metal based additive on performance emission and combustion characteristics of diesel engine fuelled with biodiesel. Appl Energy. 2011;88(11): 3694-703. https://doi.org/10.1016/j.apenergy.2011.04.043

42. Sajith V, Sobhan CB, Peterson GP. Experimental investigations on the effects of cerium oxide nanoparticle fuel additives on biodiesel. Adv Mech Eng. 2010;2:581407. https://doi.org/10.1155/2010/581407 